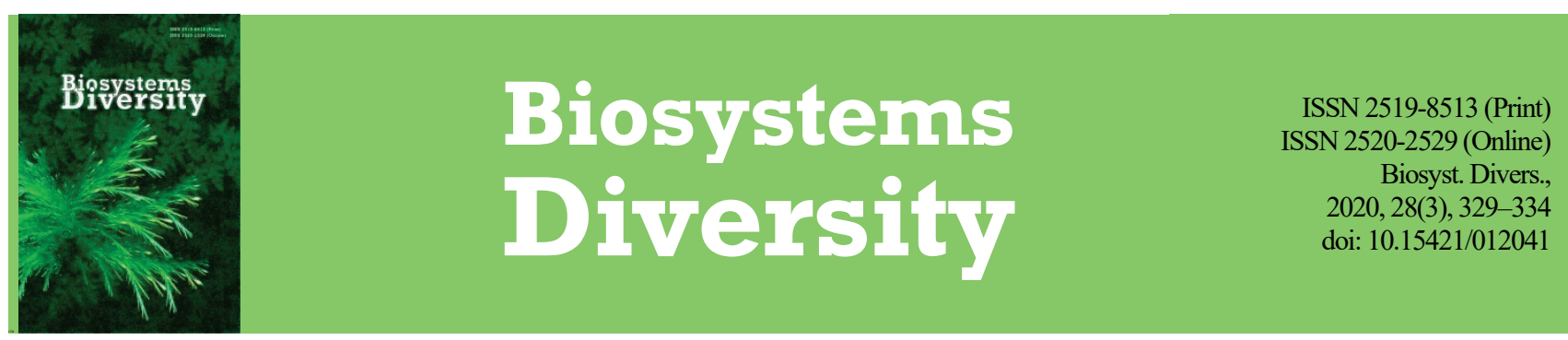

\title{
Phytoplankton of the delta of the Mekong River during the dry season
}

\author{
A. N. Sharov*, A. I. Tsvetkov*, L. G. Korneva*, C. N. Dinh** \\ Papanin Institute for Biology of Inland Waters Russian Academy of Sciences, Borok, Russia \\ Southern Branch, Vietnam - Russia Tropical Center, Ho Chi Minh City, Vietnam
}

Article info

Received 29.07.2020

Received in revised form 27.08.2020

Accepted 28.08.2020 Sharov, A. N., Tsvetkov, A. I., Korneva, L. G., \& Dinh, C. N. (2020). Phytoplankton of the delta of the Mekong River during the dry
season. Biosystems Diversity, 28(3), 329-334. doi:10.15421/012041

Human activity has disturbed the functioning of river ecosystems all around the globe. The current global climatic fluctuations and local anthropogenic impact lead to rearrangement in the structure and functioning of aquatic communities. One of the most important components of aquatic ecosystems is phytoplankton as the main primary producer of the organic matter, the basis for trophic relations and indicator of changes in the environment. This article presents the first results of a study concerning the peculiarities of quantitative distribution of biomass and species composition of phytoplankton in the delta of the Mekong River at the beginning of the dry season (December of 2018). Diatoms dominated according to biomass practically in all the stations of selection of samples. The total biomass of phytoplankton on average accounted for $0.049 \pm 0.007 \mathrm{mg} / \mathrm{L}$ at the abundance of $40 \pm 710^{3} \mathrm{ind}$./L. In practically all the studied plots, according to biomass, the dominating diatoms were first of all Aulacoseira granulata, A. islandica, Cyclotella meneghiniana, Cyclotella spp., and Oxyneis binalis. Among Chlorophyta, most often we found Chlorella sp. and Scenedesmus quadricauda, but their biomass was insignificant. We determined statistically significant correlation relationships between biomass of phytoplankton and hydrological parameters. Based on the Spearman's rank correlation coefficient, we determined negative relations between the total biomass of phytoplankton with salinity and $\mathrm{pH}$. Positive correlation was seen between the biomass of diatoms and turbidity, and also between the temperature and the biomass of chlorophytes and Dinophyta. The biomass of golden algae (Chrysophyceae) and Dinophyta positively correlated with the mineralization. Quantitative regression analysis confirmed the close relationship between the total biomass of phytoplankton, hydrophysical and hydrochemical parameters. Besides the importance of scientific data on biological diversity and ecology of plankton algae, the results we obtained are necessary for organizing biological monitoring in the delta of the Mekong River in the future.

Keywords: potamoplankton; biomass; species composition; dominating species; Vietnam; abiotic factors; estuary.

\section{Introduction}

All around the globe, phytoplankton is less studied in rivers compared with lakes and reservoirs (Soares et al., 2007). Alga-flora of a delta forms as a result of processes in a river basin, therefore the condition of algae communities in the anabranches of a delta well reflects the quality of water in the watercourse in general (Bondarenko et al., 2016). Agricultural development which has intensified over recent years and global climatic changes in the delta of the Mekong River (Parker, 2020) have made it necessary to conduct a complex integrated survey of the main components of this aquatic ecosystem, and first of all phytoplankton as the basic element of trophic networks and indicator of water quality (Gabyshev et al., 2019).

The Mekong River is 12th longest river in the world (4,505 km) and is the largest river in the South-East Asia. The Mekong has a monsoonal type of aquatic regime with sharp contrasts between humid summer and dry winter. The regime of the Mekong is characterized by alternation of rainy and dry seasons; precipitations of the summer monsoon lead to floods and in the dry season the surface runoff of the river decreases. The area of the river mouth may be identified as high-tide multi-distributary, estuary-delta type with complex interaction of monsoon fluctuations in the surface runoff, high tides, typhoons and storm surges. In the territory of Vietnam, the Mekong divides into 9 large distributaries and a considerable number of minor anabranches, forming a large delta. The area of the delta is about $40000 \mathrm{~km}^{2}$, equaling $12 \%$ of the total territory of the country (Triet et al., 2020). The river is characterized by extremely high species diversity of aquatic inhabitants. The bulk of the fish and other hydrobionts caught in the internal waters of Vietnam are those caught in the basin of the Mekong. Currently, no reliable data on the real amount of catch in the Mekong River are available, and in the recent 10-15 years the catches have significantly decreased (Boltachev et al., 2018). Decrease in the catches in the Mekong Delta is attributed to intense construction of hydroelectric stations: the streambed is blocked by dams which hinder spawning and feeding migrations of fishes and radically change the structure of the biotopes and dynamic of freshets (Boltachev et al., 2018). Poorly regulated fishing, poaching, pollution, exploitation of underwater sand beddings, aquaculture, agriculture, heavy shipping traffic and a number of other anthropogenic factors all have a negative impact (Mekong, 2020), as does global warming (Le et al., 2007).

The Mekong Delta is at the center of increasing interest due to the relative rise in the sea level (Parker, 2020). In addition to the thermosteric sea-level rise, due to thermal expansion of warming oceans and increase in the mass of melting ice from the land, the Mekong Delta is faced with excessive decline in groundwater caused by its diversion. Pumping of ground waters, infrastructural load, sand extraction and dam constructions have exacerbated the consequences of natural densification of the Holocene deposits as a result of the Delta's evolution (Zoccarato et al., 2018). During dry seasons, the Delta is affected by ingress of saline water and flooding (Le et al., 2007). Saline water penetrates further inland, and the Delta faces the problem of salinization of the soil and water-bearing horizons (Zoccarato et al., 2018). Van Manh et al. (2015) presumed that the dams and hydroelectric stations are the dominating factor. The degradation of the Mekong Delta is due to several factors, including bad schemes of management of water resources, dams and hydroelectric stations in the river basin, exhaustion of the pumps, increased pollution, expansion of the infrastructure, exploitation of the river's streambed, subsidence of the Delta, thermosteric sea,rising of the level of anthropogenic load, degradation of the shore belt of mangroves, and problems in the management of the Mekong basin (Nhan \& Cao, 2019). As a result the Delta rises and falls, posing a threat to the existence of the Delta in its current form by 2100 (Parker, 2020). Up to now, there are very little data on the structural 
parameters on the communities of hydrobionts in the delta of the Mekong River within Vietnam (Tho et al., 2012; Nguyen \& Nhien, 2020). To develop approaches to rational management of biological resources in the Mekong Delta, data on the amount and biomass of hydrobionts are required, as well as the data on peculiarities of their spatial-temporal distribution.

The objective of this article was to study the peculiarities of the distribution and the structure of biomass of phytoplankton and determine the factors underlying them in the delta of the Mekong during the dry season.

\section{Materials and methods}

The research was conducted from 5-18 December (at the beginning of the dry season) of 2018 in three distributaries of the Mekong Delta: Ham Luong, Cổ Chiên and Hau or Bassac (Fig. 1). The samples were collected from the upper horizon using Rutner's bathometer. The water samples were concentrated using direct filtration with low pressure one after another through membrane filters of $5 \mu \mathrm{m}$ diameter and then filters of $1.2 \mu \mathrm{m}$ diameter. The fixation was performed using solution with addition of normal saline and glacial acetic acid. Cameral treatment of the samples was performed according to the methods generally accepted in hydrobiology under the light microscope Mikmed-6 in the Nageotte counting chamber of $0.02 \mathrm{~mL}$ capacity. The biomass of phytoplankton was assessed using the common counting-volumetric method (Olenina et al., 2006). Species comprising over $10 \%$ of the total biomass of plankton algae were identified to the dominant species.

Hydrophysical and hydrochemical parameters of the environment (temperature, content of oxygen and its saturation, electric conductivity, total content of salts, salinity) were measured using multiparameter meter YSI ProPlus (YSI Inc, USA, 2017) along the entire water column with discreteness of one meter. The parameters were measured until the stable values were determined. The water turbidity was determined in the upper water layer using Hach 2000P turbidimeter (Hach Inc, USA, 2005) according to the standard methods recommended by the manufacturer. In spite of significantly different conditions, the device was switched to the automatic regime of measuring the range of turbidity with averaging of the measurements. Before the measuring, the device was calibrated according to the 100 NTU standard because of the universality of this standard for Mekong. Also, in the upper water layer, we determined $\mathrm{pH}$ using Hanna HI 98121 pH meter (Hanna Instruments, Inc., USA, 2012). The parameters were measured until the stable values were determined. The current speed was determined using microcomputer speedometerdischarge meter MKRS (Novye Tehnologii GK, Russia, 2015) and also Global Water Flow Probe - FP211 (Global Water, USA, 2017) in the upper layer of water by averaging the changes in the current speed.

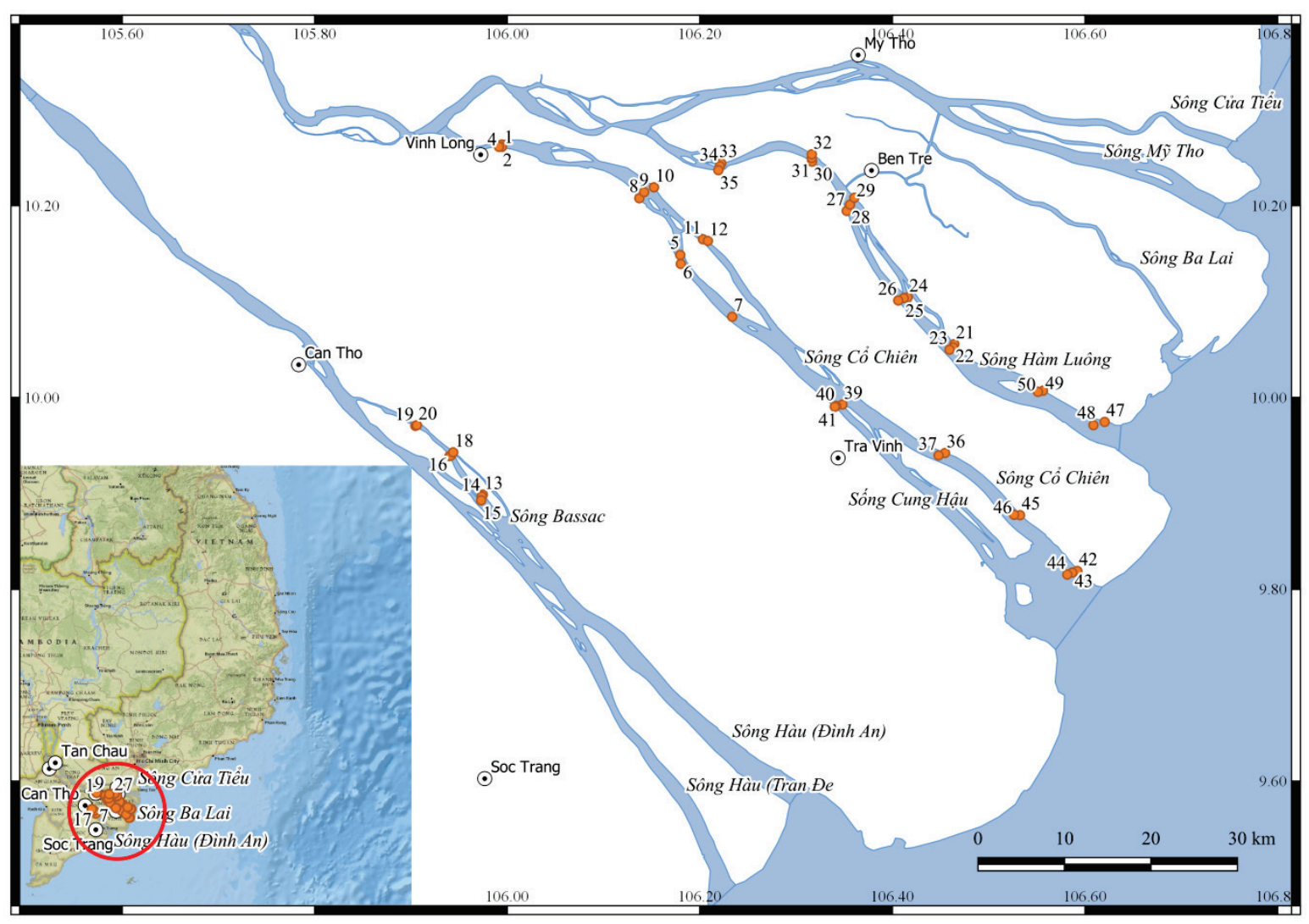

Fig. 1. Scheme of locations of the stations of sample selection in the Delta of the Mekong River

To determine the relationships between the quantitative parameters of phytoplankton and the parameters of aquatic environment we used Spearman rank coefficient (Rs), cluster, regression analyses and the principal component analysis (PCA). The calculations were performed in Statistica 10 software (StstSoft, USA, 2011). The data are given as mean value and its error $(\mathrm{x} \pm \mathrm{SE})$.

\section{Results}

Hydrological and hydrochemical characteristics. The climate in the Mekong Delta could be characterized as monsoonal. The air temperature over the year changes insignificantly: the difference between the average month values is no higher than $3{ }^{\circ} \mathrm{C}$ at average annual value of $\sim 28^{\circ} \mathrm{C}$.
Distribution of the water temperature in the Mekong Delta has a clear pattern - the temperature is higher in the upper Delta, and lower in the lower part which borders with the sea. Mean water temperatures in all the stations in December were $29.1{ }^{\circ} \mathrm{C}$ (Table 1). At the same time the difference between the temperatures in the upper and the lower parts of the Delta was $1.5^{\circ} \mathrm{C}$. The difference between the temperatures in the shallow-water shore area and deep streambed areas was practically absent, equaling $0.3^{\circ} \mathrm{C}$.

According to the content of $\mathrm{O}_{2}$, practically all the surveyed stations were characterized by high saturation $\left(70-99 \% \mathrm{O}_{2}\right)$, average concentration measuring $5.67 \pm 0.12 \mathrm{mg} / \mathrm{L}$ of $\mathrm{O}_{2}$ (Table 1). Low parameters of $\mathrm{O}_{2}$ content were seen in all the distributaries in the upper delta $\left(55-70 \% \mathrm{O}_{2}\right.$ and $4.76 \pm 0.08 \mathrm{mg} / \mathrm{L}$ of $\mathrm{O}_{2}$ ). The turbidity indicator for the distributaries and the stream course significantly differed. In the My Tho distributary it 
reached up to 121 NTU (Nephelometric Turbidity Unit) in the mouth station, whereas in the upper delta this parameter was 20 NTU.

\section{Table 1}

Change in abiotic parameters in the upper water layer of the Delta of the Mekong River in December of 2018 ( $n=50$ for each parameter)

\begin{tabular}{lccc}
\hline \multicolumn{1}{c}{ Parameter } & $\mathrm{x} \pm \mathrm{SE}$ & Min-Max & $\begin{array}{c}\text { Variation } \\
\text { coefficient, \% }\end{array}$ \\
\hline Temperature, ${ }^{\circ} \mathrm{C}$ & $29.1 \pm 0.1$ & $28-30$ & 1.4 \\
Oxygen, $\mathrm{mg} \mathrm{of} \mathrm{O} / \mathrm{L} \mathrm{L}$ & $5.67 \pm 0.12$ & $4.32-7.61$ & 15.3 \\
Oxygen saturation, $\%$ & $74 \pm 2$ & $57-99$ & 16.0 \\
Electric conductivity, $\mu \mathrm{S} / \mathrm{cm}$ & $1365 \pm 350$ & $147-12622$ & 181.4 \\
Mineralization, $\mathrm{mg} / \mathrm{L}$ & $106.0 \pm 25.3$ & $0.1-1092$ & 168.6 \\
Salinity, ppt & $0.67 \pm 0.12$ & $0.06-6.75$ & 192.1 \\
Turbidity, NTU & $49.7 \pm 3.4$ & $20.7-121.0$ & 48.3 \\
pH & $6.92 \pm 0.07$ & $6.25-7.90$ & 6.7 \\
Current speed, $\mathrm{m} / \mathrm{s}$ & $0.48 \pm 0.04$ & $0.09-1.15$ & 52.8 \\
\hline
\end{tabular}

In the Mekong and its distributaries the average current speed reached $1 \mathrm{~m} / \mathrm{s}$ and higher. During the study, the average current speed for the stations equaled $0.48 \mathrm{~m} / \mathrm{s}$ (Table 1). For the hydrodynamic processes in the mouth area of the Mekong, the most important are fluctuations in the water level associated with the high tides. The level of high tides reaches $4 \mathrm{~m}$. In the dry season, many distributaries are strongly affected by high tides, when the high-low tide discharges can significantly exceed the discharges of the river itself.

The upper dDelta was characterized by low electric conductivity of $150-170 \mu \mathrm{S} / \mathrm{cm}$ and mineralization of $88-103 \mathrm{mg} / \mathrm{L}$, and their values ranged for the horizons insignificantly. The streambed of the network of the Mekong Delta, apart from the natural distributaries, includes a dense network of irrigation and drainage canals. The canals are perhaps performing the role of refugia for saline-aquatic and even marine species by being filled with marine water during high tides, allowing it to avoid the desalination during low tides. Behind the fresh-water zone of the tributary, the transitional zone is located. It is characterized by rapid transitions in salinity, high speeds of the current. Fresh water is usually present in the upper horizons, and marine water - in the lower. Marine water was sometimes found on the sides of the mouth, and fresh water in the middle of the current. Downstream, the estuary and the mouth stations are located, which could be called the marine edge of the delta. The salinity could be characterized as intermediate (5-7\%o on the surface), whereas marine waters were found in the bed with salinity of around $30 \%$. Water salinity in the shore area of the sea reached $33 \%$.

Phytoplankton. The phytoplankton in the area of catching samples in the Mekong Delta comprised 64 species, varieties and forms of algae and Cyanobacteria, including: Cyanobacteria -1 , Chrysophyta -1 , Bacillariophyta -23 , Cryptophyta -1 , Dinophyta -1 , Charohyta -4 , Chlorophyta -33 . According to the biomass, practically in all the stations of catching, the dominants were diatoms, except station 41 (Fig. 2), located in the zone of mixing of fresh and marine water where dinoflagellates (Gymnodinium sp.) dominated. In the rest of the stations, the dominants were Aulacoseira granulata (Ehrenb.) Ralfs, 1979, Cyclotella meneghiniana Kützing, 1844, Cyclotella spp., Oxyneis (Tabellaria) binalis (Ehrenberg) Round, 1990. Among Chlorophyta, the commonest were Chlorella sp. and Scenedesmus quadricauda (Turp.) Bréb, 1835, but their biomass was insignificant, except stations 34 and 45 (Fig. 2). Cyanobacteria (Dolichospermum (Anabaena) sp.) were found in singular specimens in several stations of the Cổ Chiên and Bassac distributaries.

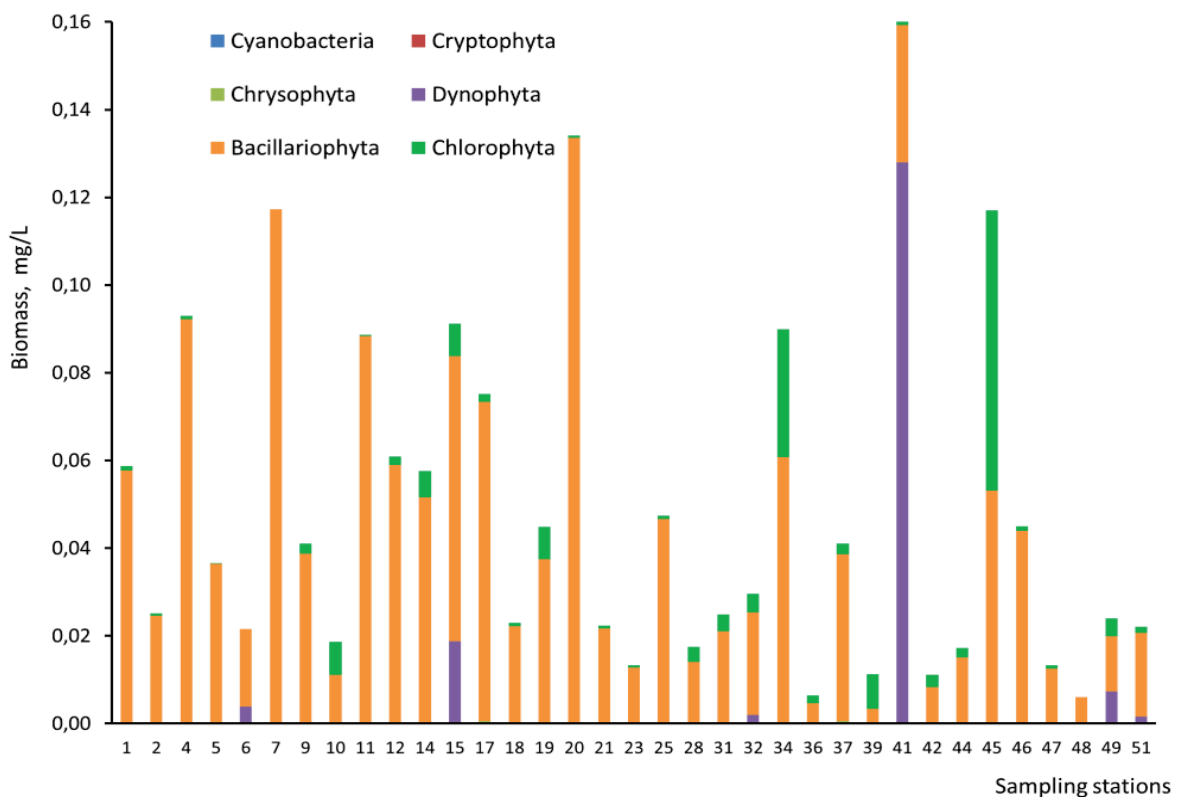

Fig. 2. Structure of biomass of different taxonomic groups of phytoplankton in the Mekong Delta in December of 2018: $1-51$ are stations of sample selections indicated in Figure 1

The biomass of phytoplankton in the Mekong Delta in December 2018 ranged $0.006-0.162 \mathrm{mg} / \mathrm{L}$ and on average accounted for $0.049 \pm$ $0.007 \mathrm{mg} / \mathrm{L}$ at the number of $40 \pm 710^{3}$ cells/L. The composition of the dominating species did not differ significantly between the distributaries (Table 2). The highest biodiversity (46 species) was observed in the Cổ Chiên distributary.

Multiple regression analysis confirmed the close relationship ( $\mathrm{P}<$ 0.05 ) between the total biomass of phytoplankton and the parameters of mineralization and turbidity in the Mekong Delta (Table 3).

Spearman correlation analysis $(n=35)$ revealed statistically significant negative relations between phytoplankton biomass and electric conductivity $\left(\mathrm{R}_{\mathrm{s}}=-0.61, \mathrm{P}=0.0001\right)$, salinity $\left(\mathrm{R}_{\mathrm{s}}=-0.62, \mathrm{P}=0.0001\right)$ and $\mathrm{pH}\left(\mathrm{R}_{\mathrm{s}}=-0.58, \mathrm{P}=0.001\right)$. Positive correlation was determined between the biomass of diatoms and turbidity $\left(\mathrm{R}_{\mathrm{s}}=0.50, \mathrm{P}=0.003\right)$, and also water temperature and biomass of Chlorophyta $\left(\mathrm{R}_{\mathrm{s}}=0.62, \mathrm{P}=0.0001\right)$, and
Dinophyta $\left(\mathrm{R}_{\mathrm{s}}=0.44, \mathrm{P}=0.009\right)$ algae. Also the mineralization positively correlated with the biomass of Chrysophyceae $\left(\mathrm{R}_{\mathrm{s}}=0.61, \mathrm{P}=0.0001\right)$ and Dinophyta $\left(\mathrm{R}_{\mathrm{s}}=0.54, \mathrm{P}=0.0008\right)$ algae.

The principal component analysis of a number of values of the phytoplankton biomass in the stations $(\mathrm{n}=35)$ of the Mekong Delta and abiotic parameters measured at the moment of sample selection revealed two main factors which contributed in total $63 \%$ of the variability of these values (Fig. 3). By the analysis of the contribution of each of the two main factors in the change of the initial variables and correlation between each other, we attempted to interpret the factors which affect the phytoplankton in the lake. Factor 1 was interpreted as the influence of the environment associated with electric conductivity, turbidity and $\mathrm{pH}$ of water, and Factor 2 - the structure of the phytoplankton community. Stations $45,15,34,7$, $20,4,11,17$ and 37 were distinguished according to the total of the factors. The rest correlate according to Factor 1. 

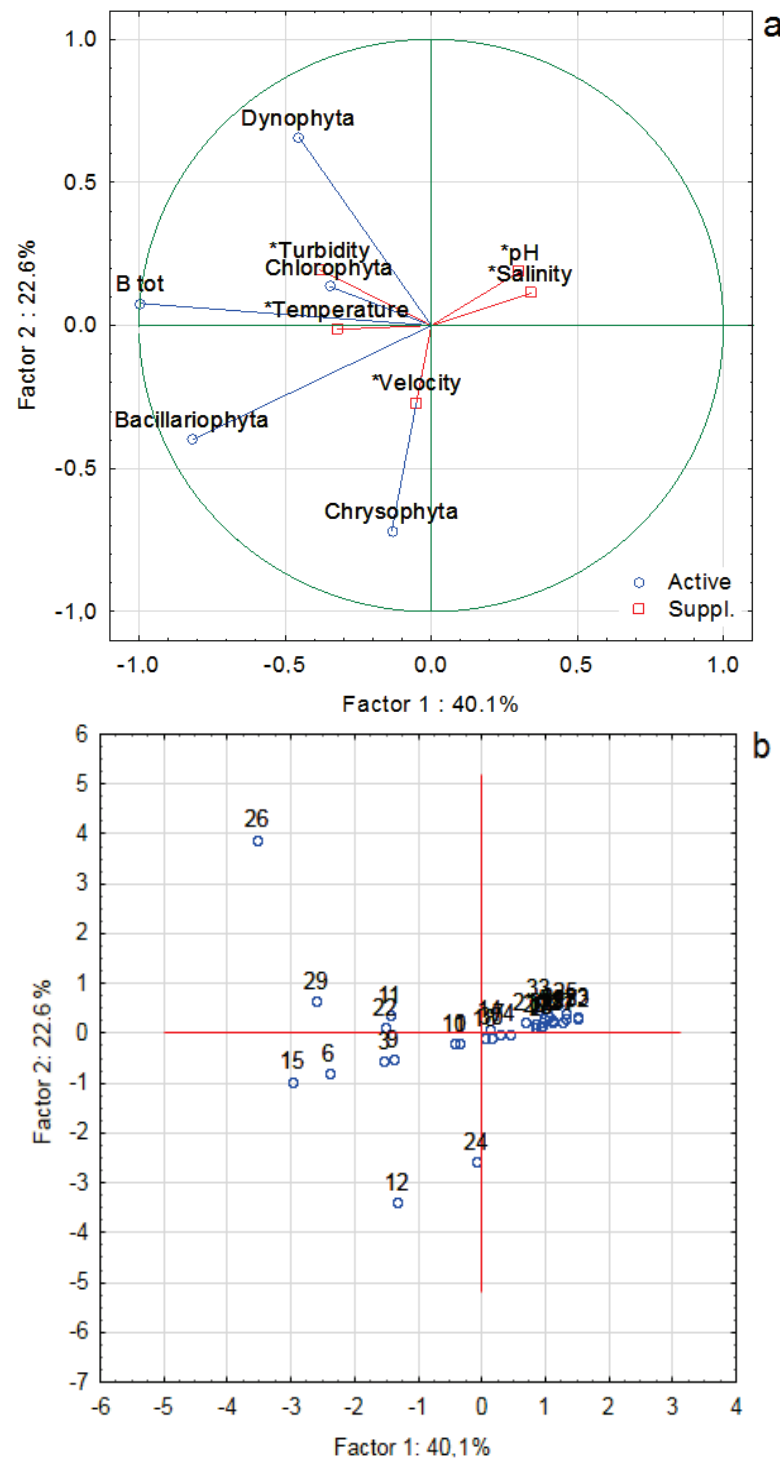

Fig. 3. Diagram of the principal component analysis of the Mekong Delta, including the abiotic variables (explanatory variables): $\mathrm{B}$ tot - the total biomass of phytoplankton; taxonomic groups: Chrysophyta, Dynophyta,

Bacillariophyta, Chlorophyta ( $\mathrm{n}=35$ according to each parameter):

$a$ - graph of the factor loads, $b$ - graph of factor coordinates

Table 2

Species of algae dominant in different distributaries of the Mekong according to biomass (December of 2018)

\begin{tabular}{lccc}
\hline Taxon & Ham Luong & Cố Chiên & Bassac \\
\hline & Dynophyta & & \\
Gymnodinium sp. & + & + & - \\
& Bacillariophyta & & \\
Aulacoseira granulata & + & + & + \\
Cyclotella spp. & + & + & + \\
Thalassiosira spp. & - & + & + \\
Stephanodiscus hantzschii & - & + & - \\
Oxyneis binalis & + & - & + \\
& Chlorophyta & & \\
Chlorella sp. & + & - & + \\
Scenedesmus spp. & + & + & + \\
\hline
\end{tabular}

Assessment of similarity of species compositions of phytoplankton revealed that both fresh-water and saline water stations of the Cổ Chiên and Hàm Luông distributaries were the closest (Fig. 4). The clustering of the data added also fresh-water stations of Hậu distributaries to them (1320). Separate clusters comprised phytoplankton of marine stations 41 and 45 (Cổ Chiên), differing by relatively high biomass of Gymnodinium sp. (Dinophyta) and Scenedesmus quadricauda (Chlorophyta).
Table 3

Results of multiple regression analysis:

hydrophysical and hydrochemical factors (water temperature, mineralization, turbidity, current speed) and the dependent variable the total biomass of phytoplankton $\left(\mathrm{R}=0.598, \mathrm{~F}_{(4.29)}=4.044\right.$, $\mathrm{P}<0.01002, \mathrm{SE}=0.85(\mathrm{n}=35)$

\begin{tabular}{lcccc}
\hline \multicolumn{1}{c}{ Parameters } & $\mathrm{b}$ & $\pm \mathrm{SE}$ & $\mathrm{t}_{(22)}$ & $\mathrm{P}$ \\
\hline Intercept & 0.000 & 0.147 & 0.000 & 1.000 \\
Temperature, ${ }^{\circ} \mathrm{C}$ & 0.207 & 0.154 & 1.345 & 0.189 \\
TDS, mg/L & -0.371 & 0.171 & -2.167 & 0.037 \\
Turbidity, NTU & 0.556 & 0.167 & 3.334 & 0.002 \\
Velocity, m/s & 0.033 & 0.151 & 0.217 & 0.829 \\
\hline
\end{tabular}

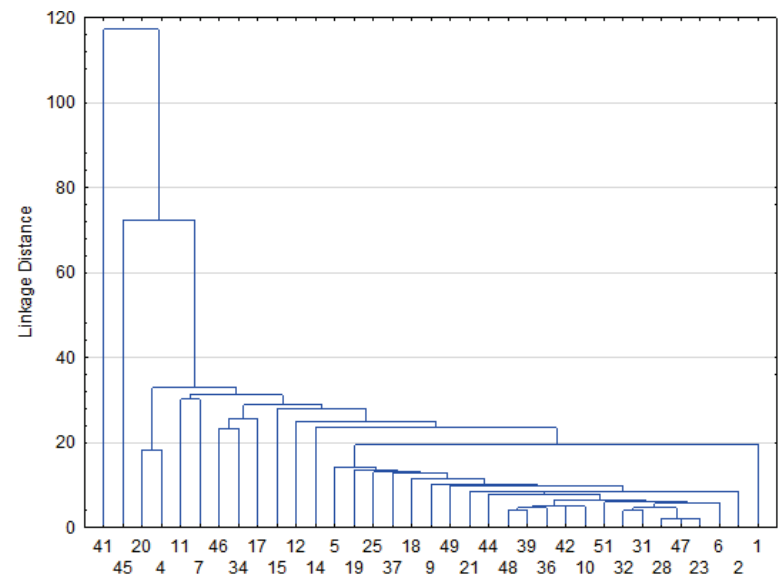

Fig. 4. Dendrogram of differences between the stations of the Mekong River according to the structure of biomass of phytoplankton in December 2018: on the ordinate axis - Euclidean distance, on the abscissa axis stations of sample selection

\section{Discussion}

The abundance and the dynamics of phytoplankton in rivers are mainly determined by hydrophysical conditions and availability of nutrients. In trophic rivers (Websret et al., 2005) the hydrological factors, the principal of which is the current velocity, significantly affect the development of phytoplankton. Unlike the rivers of the temperate zone, the development of phytoplankton in them is seen in the dry period in April-May (June) and decreases in the wet period when the amount of precipitations and velocities of rivers' currents increase (Idumah Okogwu \& Ugwumba, 2013). Anthropogenic impact such as water reservoirs and ingress of runoff water are also important to phytoplankton of rivers (Soares et al., 2007). Our studies were conducted at the end of the humid - beginning of the dry season, therefore we saw a very low level of abundance and biomass of phytoplankton. In the conditions of high current velocity $(0.48 \pm$ $0.04 \mathrm{~m} / \mathrm{s})$ and turbidity $(49.7 \pm 3.4 \mathrm{NTU})$, mainly diatom algae survived, being the most adapted to such conditions (Korneva \& Mineeva, 1986; Reynolds \& Descy, 1996). This explains the positive statistical relationship between the biomass of diatoms and water turbidity.

High turbidity, determined by a high amount of weighed particles, leads to decrease in water transparency, decrease in the photic layer, contributing to the integral primary production of algae (Korneva \& Mineeva, 1986; Silva, 2007). In trophic water bodies with high turbidity, even in the context of low concentrations of phosphorus, low amounts of primary production and chlorophyll a were observed (Lind et al., 1992; Gusev, 2014). The weighed particles are able to bind most of the phosphorus which becomes inaccessible to algae (Lind et al., 1992).

Because the studies were conducted in the river's delta, the important factors of the formation of its structural components include the degree of mineralization and water salinity. The literature data on the Mekong River are quite limited and mainly focus on some water bodies in the Mekong Delta (Tuyen, 2003; Nguyen \& Nhien, 2020). The results we obtained indicate that water salinity inhibits the development of phytoplankton. In the sample-collecting plots with heightened water salinity, lower values 
of the abundance and biomass of phytoplankton were observed. Decreases in the abundance and species diversity of phytoplankton in the conditions of increase in water salinity have been reported by many authors (Reynolds \& Descy, 1996; Silva, 2006; Jeppesen et al., 2020).

Comparison with the data on other monsoon rivers and trophic water bodies (Borges et al., 2008; Silva, 2006; Idumah Okogwu \& Ugwumba, 2013) and particularly the water reservoirs of Vietnam (Gusev, 2014a) revealed that Aulacoseira granulata was a common dominant species. However, the species composition was lower and the quantitative characteristics of phytoplankton were much lower than expected, compared to the known concentration of chlorophyll a and phosphorus in the upper layers of water of the rivers, lakes and water reservoirs of Central and Southern Vietnam (Gusev, 2014b).

According to the results of the analysis of space images taken in December 2019 and January 2020 (Mekong River Commission), a change was found in the colour of water in the lower part of the Mekong compared with the equivalent dry period in 2015 as a result of the development of Cyanobacteria. This phenomenon is explained by decrease in the amount of weighed mineral particles in the water and the development of microscopic algae as a result of the low level of water and slowing of the river current. In that period, almost no rains occurred in the downstream area of the Mekong River, while the new dams decrease the natural flow of the river.

The structure of the temperature and precipitations is predicted to noticeably change globally as a result of climate change. By the end of the XXI century, the amount of precipitations in the tropical and subtropical region is expected to decrease by $25-30 \%$, while the evaporation is expected to increase, followed by even more significant decrease in the surface runoff to $30-40 \%$ (IPCC, 2014). The scales of future changes are a serious threat to the functioning and biodiversity of internal water ecosystems. In addition to the temperature- and evaporation-driven changes, rise in the sea level will also increase the ingress of saline water to the estuary zones, and some freshwater water areas could become saline, negatively affecting the structure and functions of their biodiversity in a similar way (Flöder \& Burns, 2004; Jeppesen et al., 2007). Though the understanding of the dynamics of freshwater ecosystems and their reactions to the stressors, including climate change, is well developed, little is known about the estuaries of large rivers (Jeppesen et al., 2020). This is especially sad taking into account the duration of radical changes in many water bodies, including transition from fresh water to saline conditions and increase in salinity of already saline systems (Jeppesen et al., 2015). Moreover, mutual influence of salinization with other stressors (temperature, content of nutrients and saline composition) remains practically unknown (Jeppesen et al., 2020).

\section{Conclusions}

The initial data on the distribution of phytoplankton biomass and its species composition in the Mekong Delta in the beginning of the dry season have been obtained. Based on the analysis of the statistical relations between the abundance of phytoplankton and abiotic parameters, the research has shown that the total level of phytoplankton biomass in the Mekong Delta depended on the total of the following factors: water temperature, electro-conductivity (mineralization), turbidity, $\mathrm{pH}$ and current velocity.

Low quantitative parameters of phytoplankton (biomass of $0.049 \pm$ $0.007 \mathrm{mg} / \mathrm{L}$ and the abundance of $40 \pm 7103$ cells $/ \mathrm{L}$ ) were due to the fast current and presence of large amount of weighed particles in the water. Over the period of our studies, mass development of Cyanobacteria was not found. However, due to the predicted decrease in the surface runoff of the Mekong, we should expect a decrease in the occurrence of algal blooms.

Our results are important for monitoring and management of the Mekong Delta now and in the future in a potentially warmer climate caused by global warming. Efficient solutions for smoothing the consequences in the Mekong Delta requires cooperation between hydrologists, biologists, modelers, economists, engineers, sociologists, and also active participation of politicians and the local population. Multifaceted approaches are needed, including long-term monitoring in separate plots (currently the number of such plots is low), analysis and modeling dynamics of various processes in the hydroecosystem of the Mekong, laboratory experiments, and paleoecological analysis of bed sediments.

The authors express their sincere gratitude to the Joint Vietnamese-Russian Tropical Research and Technological Centre for financial support and organization of scientific and expedition work on the topic Ecolan E-3.4. This work was conducted with the support of the Ministry of Education and Science of Russia (On the topic AAAAA18-118012690096-1, AAAA-A18-118090390074-0).

\section{References}

Boltachev, A. R., Karpova, E. P., Statkevich, S. V., Nguyen, V. T., \& Trinh, T. L. C. (2018). Characteristics of quantitative distribution of fish and decapod crustaceans in the Mekong Delta during the low-water season of 2018. Marine Biological Journal, 3(4), 14-28.

Bondarenko, N. A., Malnik, V. V., Vishnyakov, V. S., Rozhkova, N. A., Sinyukovich, V. N., Gorshkova, A. S., Timoshkin, O. A., \& Matveyev, A. N. (2016). Modern state of the biota of the Selenga River delta (Lake Baikal basin) under conditions of unstable hydrological regime. Report 1. Microbial Community and Algae. Hydrobiological Journal, 52(1), 17-29.

Borges, P. A. F., Train, S., \& Rodrigues, L. C. (2008). Spatial and temporal variation of phytoplankton in two subtropical Brazilian reservoirs. Hydrobiologia, 607, 63-74.

Flöder, S., \& Bums, C. W. (2004). Phytoplankton diversity of shallow tidal lakes: Influence of periodic salinity changes on diversity and species number of a natural assemblage. Journal of Phycology, 40, 54-61.

Gabyshev, V. A., Tsarenko, P. M., \& Ivanova, A. P. (2019). Diversity and features of the spatial structure of algal communities of water bodies and watercourses in the Lena River estuary. Inland Water Biology, 12, 1-9.

Gusev, E. S. (2014a). Vidovoy sostav i struktura soobshchestv fitoplanktona vodokhranilishch provintsii Kkhan'khoa [Species composition and structure of phytoplankton communities in reservoirs of Khanh Hoa province]. In: Ecology of Internal Waters of Vietnam. KMK, Moscow. Pp. 84-96 (in Russian).

Gusev, E. S. (2014b). Produktsionnyye kharakteristiki i troficheskiy status vodokhranilishch Tsentral'nogo i Yuzhnogo V'yetnama [Production characteristics and trophic status of reservoirs in Central and South Vietnam]. In: Ecology of Internal Waters of Vietnam. KMK, Moscow. Pp. $74-83$ (in Russian).

Idumah Okogwu, O., \& Ugwumba, A. O. (2013). Seasonal dynamics of phytoplankton in two tropical rivers of varying size and human impact in Southeast Nigeria. Revista de Biología Tropical, 61(4), 1827-1840.

IPCC (2014). Summary for policymakers. Climate change 2014: Impacts, adaptation, and vulnerability. Contribution of Working Group II to the Fifth Assessment Report of the Intergovernmental Panel on Climate Change. Cambridge University Press, Cambridge. Pp. 1-32.

Jeppesen, E., Beklioğlu, M., Özkan, K., \& Akyürek, Z., (2020). Salinization increase due to climate change will have substantial negative effects on inland waters and freshwater resources: A call for multifaceted research at the local and global scale. The Innovation, 1(2), 100030.

Jeppesen, E., Brucet, S., Naselli-Flores, L., Papastergiadou, E., Stefanidis, K., Nõges, T., Nõges, P., Attayde, J. L., Zohary, T., Coppens, J., Bucak, T., Menezes, R. F., Freitas, F. R. S., Kernan, M., Søndergaard, M., \& Beklioğlu, M. (2015). Ecological impacts of global warming and water abstraction on lakes and reservoirs due to changes in water level and salinity. Hydrobiologia, 570, 201-227.

Jeppesen, E., Søndergaard, M., Pedersen, A. R., Jürgens, K., Strzelczak, A., Lauridsen, T. L., \& Johansson, L. S. (2007). Salinity induced regime shift in shallow brackish lagoons. Ecosystems, 10, 47-57.

Korneva, L. G., \& Mineeva, N. M. (1986). Sostav i produktivnost' fitoplanktona v vodoyemakh s vysokoy mutnost'yu [The composition and productivity of phytoplankton in water bodies with high turbidity]. In: Biology and ecology of aquatic organisms. Nauka, Leningrad (in Russian).

Le, T. V. H., Nguyen, H. N., Wolanski, E., Tran, T. C., \& Haruyama, S. (2007). The combined impact on the flooding in Vietnam's Mekong River delta of local man-made structures, sea level rise, and dams upstream in the river catchment. Estuarine, Coastal and Shelf Science, 71, 110-116.

Lind, O. T., Doyle, R., Vodopich, D. S., Trotter, B. G., Limón, J. G., \& DávalosLind, L. (1992). Clay turbidity: Regulation of phytoplankton production in a large, nutrient-rich tropical lake. Limnology and Oceanography, 37(3), 549-565.

Nguyen, G. T., \& Nhien, H. T. H. (2020). Phytoplankton-water quality relationship in water bodies in the Mekong delta, Vietnam. Applied Environmental Research, 42(2), 1-12.

Nhan, N. H., \& Cao, N. B. (2019). Damming the Mekong: Impacts in Vietnam and solutions. In: Wolanski, E., Day, J., Elliott, M., \& Ramesh, R. Coasts and estuaries. Elsevier, London. Pp. 321-340.

Olenina, I., Hajdu, S., Andersson, A., Edler, L., Wasmund, N., Busch, S., Göbel, J., Gromisz, S., Huseby, S., Huttunen, M., Jaanus, A., Kokkonen, P., Ledaine, I., \& 
Niemkiewicz, E. (2006). Biovolumes and size-classes of phytoplankton in the Baltic Sea. Baltic Sea Environment Proceedings, 106, 1-144.

Parker, A. (2020). Anthropogenic drivers of relative sea-level rise in the Mekong delta - a review. Quaestiones Geographicae, 39(1), 109-124.

Reynolds, C. S., \& Descy, J.-P. (1996). The production, biomass and structure of phytoplankton in large rivers. Archiv für Hydrobiologie (Suppl.), 113, 161-187.

Silva, E. I. L. (2007). Ecology of phytoplankton in tropical waters: Introduction to the topic and ecosystem. Asian Journal of Water, Environment and Pollution, 4(1), $25-35$.

Soares, M. C. S., Huszar, V., \& Roland, F. (2007). Phytoplankton dynamics in two tropical rivers with different degrees of human impact (Southeast Brazil). River Research and Applications, 23, 698-714.

Tho, N., Merckx, R., \& Ut, V. N. (2012), Biological characteristics of the improved extensive shrimp system in the Mekong delta of Vietnam. Aquaculture Research, 43, 526-537.
Triet, N. V. K., Dung, N. V., Hoang, L. P., Duy, N. L., Tran, D. D., Anh, T. T., Kummu, M., Merz, B., \& Apel, H. (2020). Future projections of flood dynamics in the Vietnamese Mekong delta. Science of the Total Environment, 742, 140596.

Tuyen, N. V. (2003). Biodiversity in algae in Vietnam's inland waters. Prospects and challenges. Agriculture Publishing House, Hanoi (in Vietnamese).

Van Manh, N., Dung, N. V., Hung, N. N., Kummu, M., Merz, B., \& Apel, H. (2015). Future sediment dynamics in the Mekong delta floodplains: Impacts of hydropower development, climate change and sea level rise. Global and Planetary Change, 127, 22-33.

Webster, I., Rea, N., Padovan, A., Dostine, P., Townsend, S., \& Cook, S. (2005). An analysis of primary production in the Daly River, a relatively unimpacted tropical river in Northern Australia. Marine and Freshwater Research, 56(3), 303-316.

Zoccarato, C., Minderhoud, P. S., \& Teatini, P. (2018). The role of sedimentation and natural compaction in a prograding delta: insights from the mega Mekong delta, Vietnam. Scientific Reports, 8(1), 11437. 